\begin{tabular}{ll}
\hline \hline MINING AND METALLURGY INSTITUTE BOR & ISSN: 2334-8836 (Štampano izdanje) \\
UDK: 622 & ISSN: 2406-1395 (Online) \\
\hline \hline
\end{tabular}

Dragan Zlatanovic ${ }^{*}$, Marija Ilic $^{* *}$, Vladimir Milisavljevic $^{* *}$, Dragan Ignjatovic ${ }^{* * *}$

\title{
RESULTS OF EXPERIMENTAL INSTALLATION OF ROOFBOLTING SYSTEM IN THE MINES
}

\begin{abstract}
Application of AT roofbolting system in the mines around the world has proven to be a very effective way of rockbolting support, considering that the underground facilities supported by this type of support proved to be reliable in terms of their functionality. However, despite the large and well-documented experiences, as well as extensive scientific research dedicated to this type of support, there is no serious application in the mines in our region.

This paper presents the results obtained during experimental research the possibilities of application AT roofbolting system in ensuring the stability of underground facilities. As the results, according to the tests carried out in the Bauxite Mines Niksic - mine "Biočki Stan", Coal Mine Rembas - "Strmosten" pit, as well as the Copper Mines Bor - "Jama" the underground mine.

Bellow the provided results confirm that in different geological formations can reach reliable data on the capacity of the bolt, and thus to achieve the necessary stability of underground structures using the AT roofbolting system.
\end{abstract}

Keywords: AT roofbolting system, bolt loading capacity, bolt pull-out test, stability

\section{INTRODUCTION}

Roofbolting is a system of rockbolts installed in the rock mass around underground roadway so that it can be said that the rockbolts basic element of roof bolting system. Rockbolt is mounted in a specially prepared drill hole and fixed (anchored) for the rock mass.

Rockbolts with two-component mixture (resin) - AT rockbolts, belong to the group of full column resin bond bolts, i.e. the along the complete length of the borehole. The strength of the system depends on the strength of the resin and the resin-rock interaction strength. This approach provides great resistance to shearing. The principle of anchors functionality can be described in general as resistance to the shearing forces in the roof or sidewall and on the significant limitation of roof displacement, so that the shear strength of immediate roof increases significantly.

The basic principle of bolt functionality with polymer or epoxy resins is joining the lower layers of roof with upper ones, which

\footnotetext{
* Innovation Centre, Faculty of Mechanical Engineering, Belgrade,

e-mail:dr.dragan.zlatanovic@gmail.com

*** Faculty of Mining and Geology, Belgrade, e-mail: marija.ilic@rgf.bg.ac.rs,

e-mail: vladimir.milisavljevic@rgf.bg.ac.rs

**** Mining and Metallurgy Institute Bor, e-mail:dragan.ignjatovic@irmbor.co.rs

**** This work has resulted from the Project No. TR 33021 "Investigation and Monitoring the Changes of Stress-strain in the Rock Mass "In-situ" around the Underground Rooms with Development a Model with Special Reference on the Tunel of the Krivelj River and Jama Bor", funded by the Ministry of Education, Science and Technological Development of the Republic of Serbia
} 
are still not deformed and partial filling of cracks within a resin, thus forming a stiffer beam construction. Some authors consider that this kind of support reinforces the rock mass in same way as steel reinforcement in reinforced concrete.

AT rockbolts act differently in soft, medium hard and hard rocks due to different cohesion or shear strength between the boltresin-rock, and due to various characteristics of the rock massif.

In conditions of high stress and weaker rocks in the roof, which is common in underground mines, it is necessary to apply an adequate system of reinforcement in the roof, for the efficient influence on the shear forces, which would otherwise cause a displacement in the roof and stress manifestation, resulting in caving of the roof. The rockbolt assembly consists of: bolt rod, antifriction plates, conical insert, bed-plate and screw.

In order to determine the appropriate type reinforcement and for purposes of testing, i.e. the rockbolt carrying capacity, appropriate length and diameter, baseline is determined as follows:

- The length of rockbolt can be in the range from 1.0 to $3.5 \mathrm{~m}$, considering the size of the roadway in terms of dimensions of the equipment for rockbolting.

- The diameter of rockbolt would be in the range from $19 \mathrm{~mm}$ to $26 \mathrm{~mm}$, which would imply drilling boreholes diameter from $27 \mathrm{~mm}$ to $36 \mathrm{~mm}$.

- Implementation of selected rockbolt in one or more types of rock massive, both in roof or ribs.

\section{TESTING THE ROCKBOLT CARRYING CAPACITY}

As with other systems of supporting, selection of the rockbolting system components depends on depth of underground facility, the presence of discontinuities (cracks, fissures, faults, etc.), physical and mechanical properties of the rock mass in the vicinity of underground facility, intensity and direction of natural stress and secondary stress caused by mining operations, the requirements posed in front of roof supports (e.g. an acceptable level of deformation, the life expectancy for the underground facility, etc.), shapes and sizes of underground rooms and others.

The parameters to be determined during the selection process of roofbolting system are:

- Type of bolt;

- The diameter of bolt and its carrying capacity;

- Length of bolt;

- Scheme of installation (the number of bolts in a row) and the distance between adjacent rows;

- The need for subsequent tightening of bolts.

\section{EQUIPMENT FOR INSTALLATION AND TESTING}

Resin patrons are installed in the drilled borehole. The patrons are slowly pushed to the bottom of the borehole. Rockbolt is installed with specialized drill, which is used both for drilling of boreholes and installation of bolts. The machine runs with constant rotation, pushing the bolt to the end of borehole. At the same time, the front sharpened part of the bolt breaks the patrons causing the mixing of resin components. The entire installation process takes a tenth of seconds or little bit longer. As soon as the resin solidifies (binds), rotation of the bolt is no longer possible.

Testing procedures - rockbolt pull-out test is done according to following procedure: bottom part of bolt located outside the borehole to the massif includes anti-friction plate, which is used for mounting hydraulic cylinder with a bed-plate and tightening screw. Hydraulic cylinder is connected to the hydraulic pump. Dial gauge is placed on the bottom of the bolt to measure the relative elongation during the testing. 

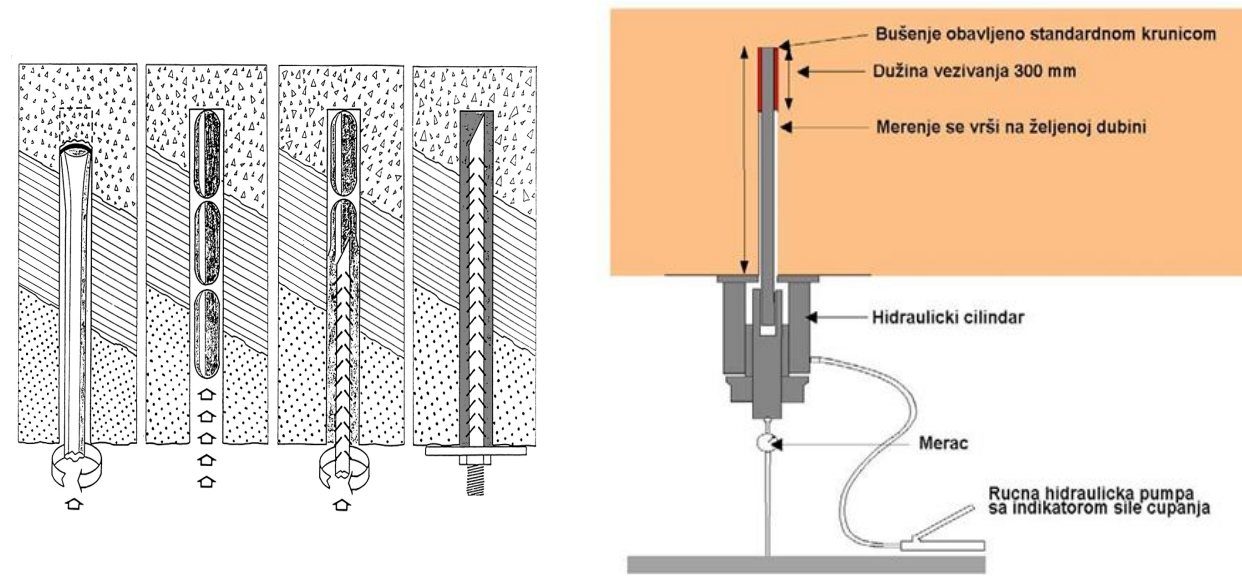

Figure 1 Principle scheme of installing bolt and the pull-out test

After all above actions, testing of carrying capacity of bolts is carried out on a pullout force using a hydraulic pump, testing is carried out according to the recommendations of the International Society for Rock Mechanics (ISRM) [1].

\section{Testing of anchors in the Bauxite Mines - Nikšić, mine "Biočki Stan"}

Installation and testing of bolts in RBN (Bauxite Mines - Nikšić) in the mine Biočki Stan was carried out in April 2001. In this period were reviewed and verified of the prepared materials and necessary equipment, defined the location for testing, drilled boreholes and installation of bolts for testing. Rockbolts are installed, testedpull-out in different time intervals. To test the rockbolt in the limestone determined hall $\mathrm{OH}-32$ and in bauxite determined hall OH-36 on P-1347 m [2].

For testing, the bolts were used of ribbed steel with diameter of $22 \mathrm{~mm}$, total length of $1.95 \mathrm{~m}$. Each bolt at one side (end) was notched at an angle of 45 degree, and at the other side (end) was threaded M-20 length $10 \mathrm{~cm}$.

The bolt rods are made at the Ironworks Nikšić from hot rolled ribbed steel C 0551R quality $570 \mathrm{~N} / \mathrm{mm}^{2}$. (Data obtained from the Ironworks Nikšić) and epoxy resin patrons from Polish production NABOJ KOTWIOWY, type OLKUSZ 3.4 Cecha WUG, length $30 \mathrm{~cm}$ and a diameter of $30 \mathrm{~mm}$.

Totally, there are 13 bolts installed ( 9 in bauxite and 4 in limestone). Seven bolts were installed with one patron of resin and six bolts with two patrons of resin.

As it can be seen in Table 1 and Figure 2 , elongation of bolts with two patrons of resin, on average, is larger than elongation of bolts installed with one patron. That can be explained by the action of the same force at short distance (not bonded part of the bolt). Displacement was measured for every 50 bar pressure increase on the hydraulic cylinder. For all installed bolts (in bauxite and limestone), the results are shown on the summary diagrams (Figure 2) for bolts with embedded one patron and with two patrons. Conclusions are as follows: 
Table 1 The values of displacement $(\Delta l,[\mathrm{~mm}])$ in the function of pull-out force-carrying capacity $(F,[k N])$

\begin{tabular}{|c|c|c|c|c|}
\hline \multicolumn{5}{|c|}{ In bauxite: OH 36 } \\
\hline \hline No. & Pressure & Force & \multicolumn{2}{c|}{ Deformation } \\
\hline 4 & $\mathrm{P}$ & $\mathrm{F}$ & 1 & $\Delta \mathrm{l}$ \\
\hline & {$[\mathrm{bar}]$} & {$[\mathrm{kN}]$} & {$[\mathrm{cm}]$} & {$[\mathrm{cm}]$} \\
\hline \multirow{2}{*}{$\begin{array}{c}\text { No. } \\
\text { of patrons } \\
\text { in drill hole }\end{array}$} & 0 & 0.0 & 8.40 & 0.00 \\
\cline { 2 - 5 } & 50 & 22.7 & 8.00 & 0.40 \\
\hline $\mathbf{1}$ & 100 & 45.4 & 7.80 & 0.20 \\
\hline & 150 & 68.0 & 7.60 & 0.20 \\
\hline & 200 & 90.7 & 7.30 & 0.30 \\
\hline & 300 & 113.4 & 7.00 & 0.30 \\
\hline & 300 & 136.1 & 6.40 & 0.60 \\
\hline & & & \multicolumn{3}{|c}{} \\
\hline
\end{tabular}

\begin{tabular}{|c|c|c|c|c|}
\hline \multicolumn{5}{|c|}{ In limestone: OH 32 } \\
\hline \hline No. & Pressure & Force & \multicolumn{2}{c|}{ Deformation } \\
\hline 1 & $\mathrm{P}$ & $\mathrm{F}$ & 1 & $\Delta \mathrm{l}$ \\
\hline & {$[\mathrm{bar}]$} & {$[\mathrm{kN}]$} & {$[\mathrm{cm}]$} & {$[\mathrm{cm}]$} \\
\hline \multirow{2}{*}{$\begin{array}{c}\text { No. } \\
\text { of patrons } \\
\text { in drill hole }\end{array}$} & 0 & 0.0 & 9.00 & 0.00 \\
\cline { 2 - 5 } & 50 & 22.7 & 8.80 & 0.20 \\
\hline $\mathbf{1}$ & 100 & 45.4 & 8.40 & 0.40 \\
\hline & 200 & 68.0 & 8.30 & 0.10 \\
\hline & 250 & 113.4 & 7.80 & 0.40 \\
\hline & 290 & 131.5 & 7.20 & 0.60 \\
\hline & 250 & 113.4 & & \\
\hline
\end{tabular}

\begin{tabular}{|c|c|c|c|c|}
\hline No. & Pressure & Force & \multicolumn{2}{|c|}{ Deformation } \\
\hline 5 & $\mathrm{P}$ & $\mathrm{F}$ & 1 & $\Delta \mathrm{l}$ \\
\hline & {$[\mathrm{bar}]$} & {$[\mathrm{kN}]$} & {$[\mathrm{cm}]$} & {$[\mathrm{cm}]$} \\
\hline \multirow{2}{*}{$\begin{array}{c}\text { No. } \\
\text { of patrons } \\
\text { in drill hole }\end{array}$} & 0 & 0.0 & 8.20 & 0.00 \\
\cline { 2 - 5 } & 50 & 22.7 & 7.70 & 0.50 \\
\hline $\mathbf{2}$ & 100 & 45.4 & 7.20 & 0.50 \\
\hline & 200 & 68.0 & 6.80 & 0.40 \\
\hline & 250 & 113.4 & 6.00 & 0.60 \\
\hline & 300 & 136.1 & 5.70 & 0.30 \\
\hline & 310 & 140.6 & 5.00 & 0.70 \\
\hline & 280 & 127.0 & puklo & \\
\hline
\end{tabular}

\begin{tabular}{|c|c|c|c|c|}
\hline No. & Pressure & Force & \multicolumn{2}{|c|}{ Deformation } \\
\hline 3 & $\mathrm{P}$ & $\mathrm{F}$ & 1 & $\Delta \mathrm{l}$ \\
\hline & {$[\mathrm{bar}]$} & {$[\mathrm{kN}]$} & {$[\mathrm{cm}]$} & {$[\mathrm{cm}]$} \\
\hline \multirow{2}{*}{$\begin{array}{c}\text { No. } \\
\text { of patrons } \\
\text { in drill hole }\end{array}$} & 0 & 0.0 & 4.50 & 0.00 \\
\cline { 2 - 5 } & 50 & 22.7 & 4.30 & 0.20 \\
\hline $\mathbf{2}$ & 100 & 45.4 & 3.90 & 0.40 \\
\hline & 200 & 68.0 & 3.80 & 0.10 \\
\hline & 250 & 113.4 & 3.40 & 0.20 \\
\hline & 300 & 136.1 & 3.00 & 0.40 \\
\hline & 310 & 140.6 & & \\
\hline & & & & \\
\hline
\end{tabular}
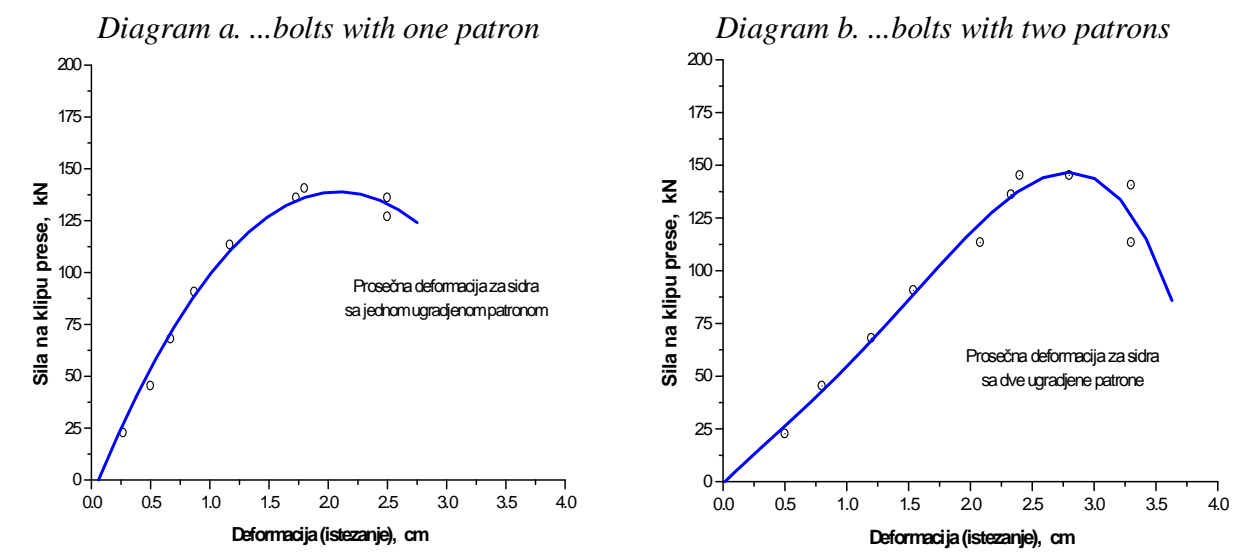

Figure 2 Diagrams - results of measuring the pull-out force of bolts in the "Biočki Stan " mine 
- The rockbolts with one patron at the maximum force of $145.2 \mathrm{KN}$ (320 bar) comes to elongation-deformation of $2.00 \mathrm{~cm}$, diagram a;

- The rockbolt with two patrons at the same force comes to the elongationdeformation of $2.70 \mathrm{~cm}$, diagram $\mathrm{b}$.

In the case of failure on the thread it was not possible to precisely determine the exact carrying capacity of rockbolt. In this instance, it is known that bolts were loaded with more than $130 \mathrm{KN}$ (tensile force).

Based on the performed experimental testing of loading capacity of bolts, it can be concluded that the force exerted on the threads of the bolts is in the range 90-110 $\mathrm{KN}$, and breakout forces is in the range 120-140 KN. Also, tested bolts are completely in accordance to the prescribed quality as defined by standards and manufacturers certificates.

\section{Pull-out testing of AT rockbolts in the Coal Mine REMBAS, Pit "Strmosten"}

Experimental installation of AT roof support was performed at this location in a period starting in 2004. Prior to start the regular installation of support, nine pullout tests were performed on three selected locations in roadways TH-4 and GTH-2. It was estimated, as realistic possibility, that the crushed material could have negative impact on tests results. Bolts were made of $22 \mathrm{~mm}$ steel, and installed in $27 \mathrm{~mm}$ boreholes. Testing was done with fast set resin, supplied by Carbotech. The obtained results are given in following table [3]:

Table 2 Pull-out test results of short bonded rockbolt

\begin{tabular}{|c|c|c|c|c|c|}
\hline Test no. & Location & Rock type & $\begin{array}{l}\text { Depth } \\
{[\mathrm{m}]}\end{array}$ & $\begin{array}{c}\text { Bond strength } \\
{[\mathrm{kN}]}\end{array}$ & Comment \\
\hline 1 & \multirow{3}{*}{ TH-4 } & \multirow{3}{*}{$\begin{array}{c}\text { Rock above } \\
\text { coal }\end{array}$} & \multirow{3}{*}{2.4} & 123 & App. $10 \%$ clay at top of the hole \\
\hline 2 & & & & 85 & App. $30 \%$ clay at top of the hole \\
\hline 3 & & & & 95 & App. $30 \%$ clay at top of the hole \\
\hline 4 & \multirow{3}{*}{ TH-4 } & \multirow{3}{*}{ Coal } & \multirow{3}{*}{1.0} & 28 & \\
\hline 5 & & & & $>70$ & $\begin{array}{l}\text { Gauge removed at } 70 \mathrm{kN} \text {; } \\
\text { Bolt loaded to } 95 \mathrm{kN} \text {. }\end{array}$ \\
\hline 6 & & & & 28 & \\
\hline 7 & \multirow{3}{*}{ GTH-2 } & \multirow{3}{*}{$\begin{array}{l}\text { Red sand- } \\
\text { stone }\end{array}$} & \multirow{3}{*}{1.1} & 37 & \multirow{3}{*}{$\begin{array}{l}\text { Sandstone completely crushed } \\
\text { under load. }\end{array}$} \\
\hline 8 & & & & 28 & \\
\hline 9 & & & & - & \\
\hline
\end{tabular}

It should be mentioned that the "bond strength" means reducing stiffness of the bolt - resin - rock interaction strength, below the $20 \mathrm{kN} / \mathrm{mm}$ of connection.
In order to evaluate test as a successful one, recommended loading of short bonded bolt (in length of $300 \mathrm{~mm}$ ) should be $130 \mathrm{kN}$, which should be achieved along the more of $50 \%$ of boreholes. 


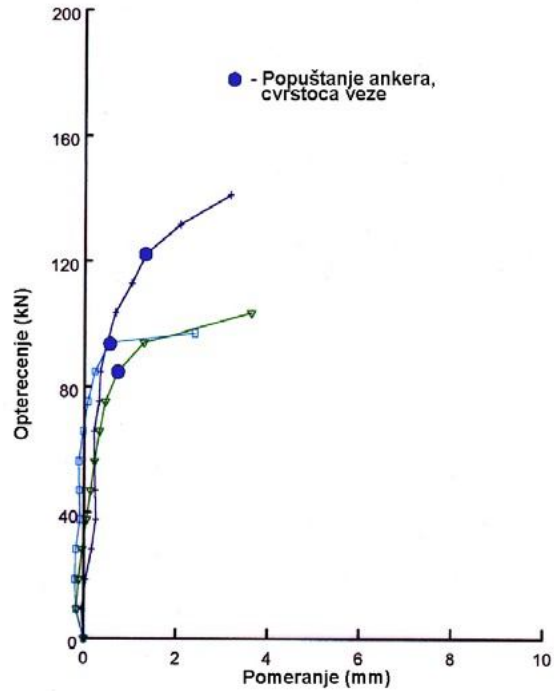

a) TH-4, length $2.4 \mathrm{~m}$, rock above coal

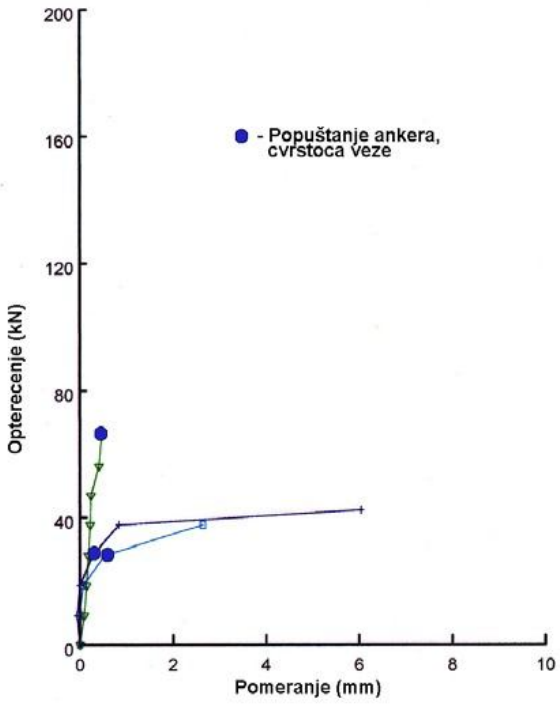

b) TH-4 length $1.0 \mathrm{~m}$, coal

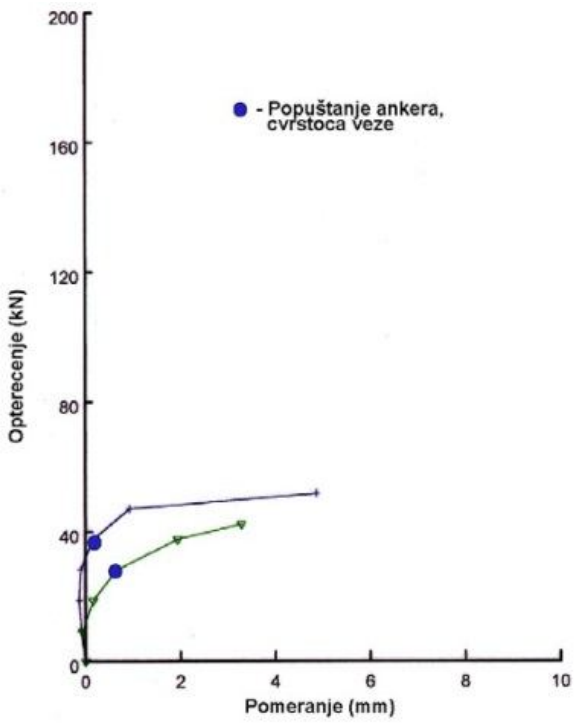

c) GTH-2, length $1.1 \mathrm{~m}$, sandstone

Figure 3 Pull-out test results obtained in Strmosten pit of the Mine REMBAS

Results are indicating that force of $123 \mathrm{kN}$ can be achieved at locations where bolt is installed in sandstone or marlstone, while forces from 70 to $95 \mathrm{kN}$ can be expected in coal. Crushed and disturbed rocks around the roadways probably had negative impact on some test results. 
It was concluded that criteria were met, and that AT roof support installed in $\mathrm{TH}-4$ roadway in Strmosten pit of REMBAS mine can be evaluated as efficient. Also, it is proved that theroof support reacted with surrounding rocks, resisting to both vertical and horizontal loading.

The obtained stability of roadway achieved with AT roof support, largely reduces requirements for later reconstructions, as well as providing the base for future research regarding support optimization mainly related to increasing the spacing between steel sets, with possibi- lity for complete elimination of steel support.

\section{Testing of bolts performed in the Coper Mines Bor, ,Jama“underground mine}

During underground mining, parallel with the exploitation ore body "T1", the supporting of excavated area is carried out. Supporting is carried out by means of bolts of type SWELLEX and SN, M-20 in a combination with the resin LOKSET RESIN CAPSULES. Supporting is preceded by drilling of boreholes for installation of anchors. Hole diameter is $\varnothing 33 \mathrm{~mm}$ and length $3 \mathrm{~m}$. [4]

Table 3 The values of displacement $(\Delta l,[\mathrm{~mm}])$ in the function of pull-out force-carrying capacity $(F,[k N])$

\begin{tabular}{|c|c|c|c|c|c|}
\hline \multicolumn{6}{|c|}{ Bolt - testing place } \\
\hline \multicolumn{2}{|c|}{ Test 1, room side, K-145 } & \multicolumn{2}{|c|}{ Test 2 , right side, K-145 } & \multicolumn{2}{|c|}{ Test 3, left side, K-145 } \\
\hline$\Delta \mathrm{l},[\mathrm{mm}]$ & $\mathrm{F},[\mathrm{kN}]$ & $\Delta \mathrm{l},[\mathrm{mm}]$ & $\mathrm{F},[\mathrm{kN}]$ & $\Delta \mathrm{l},[\mathrm{mm}]$ & $\mathrm{F},[\mathrm{kN}]$ \\
\hline 4.30 & 18.64 & 7.00 & 18.64 & 1.00 & 9.32 \\
\hline 8.80 & 46.60 & - & - & 2.60 & 18.64 \\
\hline 10.00 & 55.92 & - & - & 3.30 & 37.28 \\
\hline 11.30 & 65.24 & - & - & 4.20 & 46.60 \\
\hline 12.60 & 74.56 & - & - & 4.80 & 55.92 \\
\hline 14.20 & 83.88 & - & - & 5.00 & 65.24 \\
\hline 15.70 & 82.30 & - & - & 5.80 & 74.56 \\
\hline- & - & - & - & 7.00 & 83.88 \\
\hline \multicolumn{6}{|c|}{ Bolt - testing place } \\
\hline \multicolumn{2}{|c|}{ Test 1 , right side, K-123 } & \multicolumn{2}{|c|}{ Test 2, right side, $\mathrm{K}-123$} & \multicolumn{2}{|c|}{ Test 3, roof of room, K-123 } \\
\hline$\Delta \mathrm{l},[\mathrm{mm}]$ & $\mathrm{F},[\mathrm{kN}]$ & $\Delta \mathrm{l},[\mathrm{mm}]$ & $\mathrm{F},[\mathrm{kN}]$ & $\Delta \mathrm{l},[\mathrm{mm}]$ & $\mathrm{F},[\mathrm{kN}]$ \\
\hline 7.10 & 18.64 & 3.00 & 18.64 & 2.00 & 18.64 \\
\hline 7.60 & 27.96 & 3.20 & 27.96 & 6.10 & 27.96 \\
\hline 8.20 & 37.28 & 4.00 & 37.28 & 7.50 & 37.28 \\
\hline 8.40 & 46.60 & 5.90 & 46.60 & 10.50 & 46.60 \\
\hline 8.50 & 55.92 & 6.00 & 55.92 & 11.00 & 55.92 \\
\hline 9.20 & 65.24 & 7.10 & 65.24 & 13.00 & 60.58 \\
\hline 13.30 & 74.56 & 7.40 & 74.56 & 14.00 & 65.24 \\
\hline 15.90 & 83.88 & 8.00 & 83.88 & 14.80 & 74.56 \\
\hline 17.70 & 93.20 & 9.80 & 93.20 & 15.00 & 83.88 \\
\hline 18.60 & 102.52 & 9.90 & 102.52 & 15.10 & 93.20 \\
\hline 19.40 & 111.84 & 10.00 & 111.84 & 16.00 & 102.52 \\
\hline 23.50 & 121.16 & 12.90 & 121.16 & 16.30 & 111.84 \\
\hline 26.00 & 130.48 & 13.00 & 130.48 & 16.50 & 121.16 \\
\hline 27.00 & 135.14 & 13.50 & 139.80 & 25.50 & 130.48 \\
\hline- & - & 16.70 & 149.12 & - & - \\
\hline- & - & 17.40 & 153.78 & - & - \\
\hline
\end{tabular}


After installation the bolts and tightening of nut, the reinforcement mesh is installed and shotcrete is applied. In addition to the pull-out force, displacements of bolt head are also measured. Pull-out force is applied gradually to achieve the set (working) or limit pull-out force. The results of testing the carrying capacity of rockbolts are presented by graphic diagrams of movements in the function of pull-out force.

Measurements were performed twice (November 2013 and January 2014) on 6 bolts, which are installed on the specific locations in the ore body $\mathrm{T} 1$.

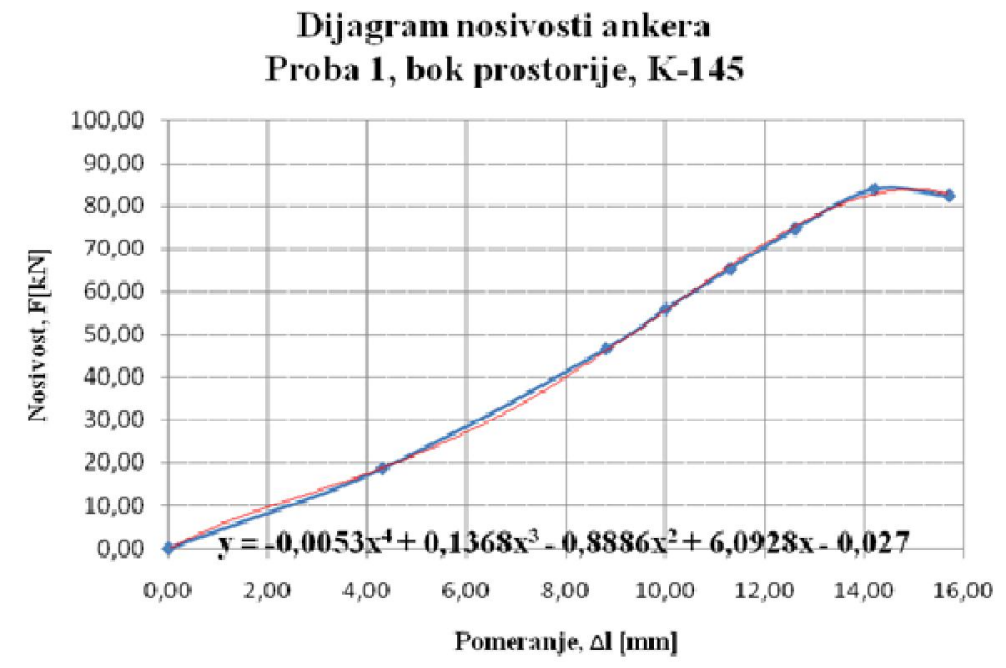

Dijagram nosivosti ankera Proba 3, strop prostorije, raskrsnica, K-123

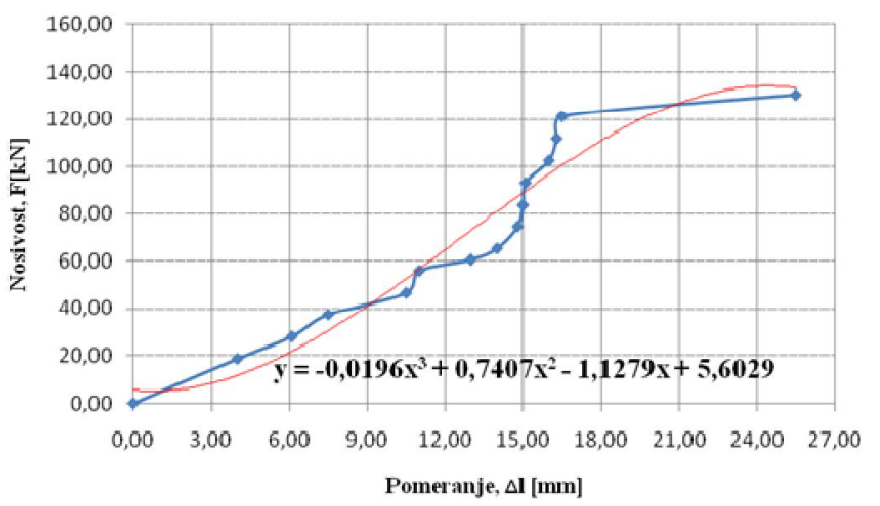

Figure 4 Diagrams - results of measuring the pull-out force for of the bolts in the "Jama" underground mine

Values of pull - out forces of bolts were compared with the specification and certificates given by the manufacturer and it can be concluded that the anchors completely fulfil their functions. 


\section{ANALYSIS OF THE RESULTS}

Tests of rockbolts anchors with full column resin bond (AT roofbolting system) are an example of experimental testing in different working environments verify that they meet the desired function and have the following advantages [6]:

- The link between the bolt and rock mass is easier to achieve, and connection is very reliable and independent of the type of rocks;

- Efficiency of bolts is permanent along the entire length of the bolt;

- Full column resin bonded rockbolts are preventing vertical and horizontal deformation of massif;

- The depth of drill hole is not the key parameter, since the connection between the bolt and massif can be matched to the type of rocks;

- Full column resin bonded rockbolts prevent the flow of water and air flow, thus eliminating corrosion and the impact of moisture on the rock (weathering);

- Damaged nuts, thread and other components of the bolt, as well as crushing rocks around the bolt, does not reduce the effectiveness of the connection bolt-mixture-rock;

- Bolts with a two-component mixture (based on polymer resins) can withstand the impact of mining without loss of capacity and

Also, the data on load testing capacity of full column resin bonded rockbolts represent relevant input data for the budgeting of projects related to calculation the capacity and stability analysis of underground structures.

\section{CONCLUSION}

Experimental efficiency testing was determined for AT roof support, which prevents propagation of deformation along depth of massif (which is evidence of achieving stability of underground facilities) and to transfer the load from rock to AT roof support.

Rated capacity of the tested bolts with diameter of $22 \mathrm{~mm}$ can be accepted as a carrying capacity of value $150 \mathrm{kN}$ (extension strength).

Actual results provide opportunities for further research regarding the optimization of supporting primarily towards installation patterns and scheduling of installation, as well as determining the required number of cartridges per borehole. It has been noted that in some cases, the bolt bonded with only one cartridge $30 \mathrm{~cm}$ long $(50 \mathrm{~cm}$ length of bonding) are not yielded and there were no failures. This raises the question of the possibility of optimizing the number of cartridges or length of bonding anchors into the hole depending on the length of bolt and characteristics of the rock mass.

\section{REFERENCES}

[1] ASTM F432-04, Standard Specification for Roof and Rock Bolts and Accessories, ASTM International, Pennsylvania, USA, 2004;

[2] Study Title - "Elaborate on Testing and Issuing Certificates for Steel Anchors with Two-component Mixture, Introduction the Anchoring technology in the Boxite Mines Niksic - I Phase", Mining Institute, Zemun, May, 2001 (in Serbian); 
[3] V. Milisavljević, $\mathrm{PhD}$ dissertation, Selection the System of AT Elements of Hanging Roof Supports for Coal Mines with Underground Mining in Serbia, Faculty of Mining and Geology, Belgrade, 2010 (in Serbian);

[4] Quarterly Report on Condition of Works in Ore Mining from the Ore Body "T1", Mining and Metallurgy Institute in Bor, March 2014 (in Serbian);

[5] D. Ignjatović, L. Đurđevac Ignjatović, M. Ljubojev, I. Ivanov, Testing the Bearing Capacity of Anchors in the
Ore body "T1", Mining and Metallurgy Engineering Bor, 1/2014, p. 1-6, 2014 (in Serbian);

[6] Peng, S. and Tang, D.: Roof Bolting in Underground Mining: State of the Art View, International Journal of Mining Engineering, Volume 2, 1984, pp. 1-4.

[7] M. Ljubojev, M. Avdić, L. Đurđevac Ignjatović; State Around the Mine Workings; $44^{\text {th }}$ International October Conference on Mining and Metallurgy, 1-3 October 2012, Bor, Serbia, pp. 245-248. 


\begin{tabular}{ll}
\hline \hline INSTITUT ZA RUDARSTVO I METALURGIJU BOR & ISSN: 2334-8836 (Štampano izdanje) \\
UDK: 622 & ISSN: 2406-1395 (Online) \\
\hline \hline
\end{tabular}

UDK: $622.272 / .283 .4(045)=163.41$

DOI:10.5937/MMEB1404065Z

Dragan Zlatanovic ${ }^{*}$, Marija Ilic $^{* *}$, Vladimir Milisavljevic ${ }^{* *}$, Dragan Ignjatovic ${ }^{* * *}$

\section{REZULTATI EKSPERIMENTRALNE UGRADNJE AT VISEĆE PODGRADE U RUDNICIMA******}

Izvod

Primena AT viseće podgrade u rudnicima širom sveta se pokazala kao veoma efikasan način podgrađivanja, obzirom da su se podzemni objekti podgrađeni ovom vrstom podgrade pokazali kao pouzdani u smislu njihove funkcionalnosti. Međutim, pored velikog $i$ dobro dokumentovanog stečenog iskustva, kao i obimnog naučno-istraživačkog rada posvećenog ovoj vrsti podgrade, u rudnicima na našim prostorima još uvek nije našlo ozbiljniju primenu.

U ovom radu su prikazani rezultati dobijeni tokom eksperimentalnih istraživanja mogućnosti primene AT viseće podgrade kod osiguranja stabilnosti podzemnih objekata. Kao rezultati, navode se testiranja obavljena u Rudnicima boksita Nikšić - jami „Biočki stan“, Rudniku uglja Rembas - jami „Strmosten“, kao i Rudnicima bakra u Boru - rudniku „Jama“.

Upravo i ovi rezultati potvrđuju da u različitim geološkim formacijama možemo doći do pouzdanih podataka o nosivosti ankera, a samim timi da ostvarimo potrebnu stabilnost podzemnih objekata primenom AT viseće podgrade.

Ključne reči: AT viseća podgrada, nosivost ankera, test čupanja ankera, stabilnost

\section{UVOD}

Viseća podgrada predstavlja sistem ankera ugrađenih u stenski masiv oko podzemnog objekta, tako da se može reći da je anker osnovni element viseće podgrade. Anker se ugrađuje u posebno pripremljenu bušotinu i učvršćeno je (ukotvljeno) za stenski masiv.

Ankeri sa dvokomponentnom smešom AT ankeri (eng. Advanced Technology), spadaju u grupu ankera koja nose (vezuju) po celoj svojoj dužini, odnosno dužini bušotine. Čvrstoća sistema zavisi od čvrstoće smeše i čvrstoće veze. Visoka čvrstoća veze (anker-smeša-stena) obezbeđuje veliki otpor na smicanje. Princip delovanjaankera se svodi na direktno suprostavljanje na smicanje u krovini ili boku (stubu) i na što veće ograničavanje pomeranja krovine, tako da se čvrstoća na smicanje direktne krovine (boka) značajno povećava.

Osnovni princip delovanja ankera sa dvo-komponentnom smešom (polimernim ili epoksidnim smolama) predstavlja spajanje donjih slojeva krovine sa gornjim,

\footnotetext{
* Inovacioni Centar Mašinskog fakulteta,Beograd, e-mail: dr.dragan.zlatanovic@gmail.com

*** Rudarsko-geološkifakultet, Beograd, e-mail: marija.ilic@rgf.bg.ac.rs,

vladimir.milisavljevic@rgf.bg.ac.rs

*** Institut za rudarstvo i metalurgiju, Bor, e-mail: dragan.ignjatovic@irmbor.co.rs

***** Rad je proizašao iz projekta broj TR 33021 „Istraživanje i praćenje promena naponsko deformacijskog stanja u stenskom masivu ,,in-situ“ oko podzemnih prostorija sa izradom modela sa posebnim osvrtom na tunel Kriveljske reke i Jame Bor", koji je finansiran sredstvima Ministarstva za prosvetu, nauku i tehnološki razvoj Republike Srbije
} 
neporemećenim slojevima, povezivanjem i delimičnim ispunjavanjem pukotina smešom, čim se navedeni slojevi pretvaraju u čvrstu grednu konstrukciju. Neki autori smatraju da ova vrsta podgrade učvršćuje stenski masiv analogno armiranju kod armiranog betona.

AT ankeri različito deluju u mekim, srednje čvrstim i čvrstim stenama zbog različite kohezije ili čvrstoće na smicanje između ankera i smeše, kao i između smeše i zidova bušotine, a zbog različitih karakteristika stenskog materijala.

U uslovima velikih napona i slabijih stena u krovini, što je čest slučaj u rudnicima sa podzemnom eksploatacijom, neophodno je primeniti adekvatan sistem ojačanja u krovini, radi efikasnog uticaja na aktivno smicanje, koje će u suprotnom izazvati pomeranje krovine i manifestaciju napona, što izaziva zarušavanje krovine.

Sam sklop ankera čine: šipka ankera, antifrikciona ploča, konični umetak, podloška i zavrtanj.

$\mathrm{Za}$ potrebe ispitivanja ankera $\mathrm{u}$ cilju utvrđivanja odgovarajućeg tipa ankera, potrebne nosivosti tj. odgovarajuće dužine i prečnika, polazna osnova će biti sledeća:

- Dužine ankera mogu se kretati u granicama od 1,0 do 3,5 m, vodeći pri tome računa o veličini profila koji se podgrađuje sa aspekta gabarita opreme za ankerisanje.

- Prečnici ankera bi bili u opsegu od $19 \mathrm{~mm}$ do $26 \mathrm{~mm}$, što bi značilo bušenje bušotina prečnika od $28 \mathrm{~mm}$ do $36 \mathrm{~mm}$.

- Primena izabranog tipa ankera u jednoj ili više radnih sredina: krovini i/ili bokovima.

\section{ISPITIVANJE NOSIVOSTI ANKERA}

Kao i kod ostalih sistema podgrađivanja, tako i kod viseće podgrade, izbor elemenata sistema zavisi od dubine na kojoj se nalazi podzemni objekat, prisustva diskontinuiteta (pukotina, raseda i dr.), fizičko-mehaničkih osobina stenskog masiva u okolini podzemnog objekta, intenzitetu i smeru prirodnih napona i naknadnih napona nastalih usled rudarskih radova, zahteva koji se postavljaju pred podgradu (npr. prihvatljiv nivo deformacija, očekivani vek podzemnog objekta i sl.), oblika i dimenzija podzemne prostorije i dr.

Parametri koje treba odrediti pri izboru elemenata sistema viseće podgrade su:

- Vrsta ankera;

- Prečnik ankera i nosivost ankera;

- Dužina ankera;

- Šema ugradnje (broj ankera u jednom redu) i rastojanje između susednih ankera;

- Potreba za naknadnim zatezanjem ankera.

\section{OPREMA ZA UGRADNJU I ISPITIVANJE ANKERA}

U izbušenu i očišćenu bušotinu ubacuje se određeni broj patrona dvokomponentne smeše. Patrone se sa ankerom lagano gurnu do dna bušotine. Na slobodan kraj ankera namešta se odgovarajuća rotaciona bušilica sa specijalnim ključem koji se postavlja na navoj na kraju ankera. Mašina se pokreće i uz stalnu rotaciju, anker se gura do kraja bušotine. Tom prilikom, prednji zašiljeni deo ankera kida plastični omotač patrona tako da dolazi do mešanja komponenti, želiranja i očvršćavanja smeše. Ceo postupak ugradnje traje desetinu sekundi ili nešto duže. Čim smeša uhvati (veže) prestaje mogućnost rotacije ankera.

Sama procedura ispitivanja - čupanja ankera je sledeća: na slobodni deo ankera koji se nalazi van bušotine se do masiva postavlja podložna test ploča, montira hidraulična presa sa podloškom i maticom koja se zategne. Hidraulična presa (cilindar) se povezuje sa hidrauličnom pumpom, a komparater se postavlja na vrh (kraj) ankerne šipke da meri relativno izduženje šipke prilikom čupanja. 

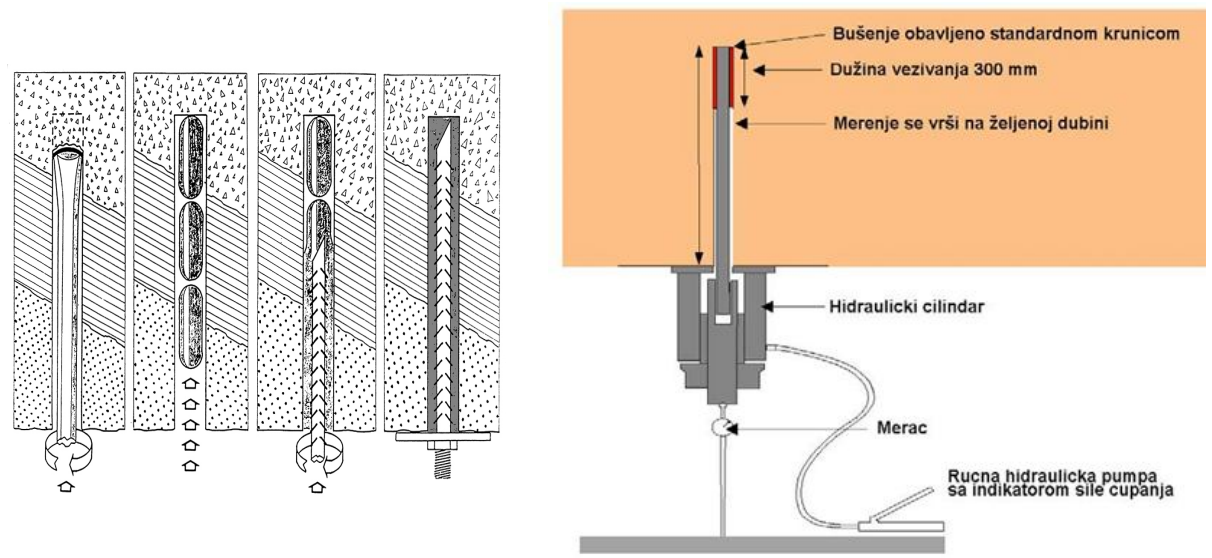

Sl. 1. Princip ugradnje ankera sa šemom testa čupanja ankera

Posle svih navedenih radnji, ispitivanja nosivosti ankera na silu čupanja pomoću hidraulične pumpe, vrši se prema preporukama Međunarodnog društva za mehaniku stena (ISRM). [1]

\section{Ispitivanje ankera u Rudnicima boksita - Nikšić, jami ,Biočki stan““}

Ugradnja i testiranje ankera $\mathrm{u} R \mathrm{RBN} \mathrm{u}$ jami Biočki Stan je izvršeno aprila 2001. godine. U tom periodu je izvršen pregled i provera pripremljenog materijala i potrebne opreme, određena lokacija za testiranje, izbušene bušotine i ugrađeni ankeri za testiranje. Tako ugrađeni ankeri su u različitim vremenskim intervalima testirani - čupani. Zatestiranje u krovinskom krečnjaku određen je otkopni hodnik $\mathrm{OH}-32$, a za testiranje u boksitu OH-36 na P-1347 m.[2]

$\mathrm{Za}$ testiranje su korišćena testni ankeri od betonskog rebrastog čelika prečnika ф $22 \mathrm{~mm}$, ukupne dužine 1,95 m. Svaki anker je na jednom kraju bio zasečen pod uglom od $45^{\circ}$, a na drugom kraju je bio narezan navoj M-20 dužine $10 \mathrm{~cm}$.

Šipke su izrađene u Željezari Nikšić od toplovaljanog betonskog rebrastog čelika
C $0551 R$ kvaliteta $570 \mathrm{~N} / \mathrm{mm}^{2}$. (Podaci dobijeni od Željezare Nikšić), a patrone epoksidne smole su Poljske proizvodnje NABOJ KOTWIOWY, tip OLKUSZ 3,4 Cecha W.U.G., dužina patrone $30 \mathrm{~cm} \mathrm{i}$ prečnikom patrone $30 \mathrm{~mm}$.

Od ukupno 13 ankera ( 9 u boksitu i 4 u krečnjaku) sedam ankera je ugrađeno sa jednom patronom, a šest ankera sa dve patrone.

Iz tabela, odnosno dijagrama se vidi da je istezanje ankera kod dve patrone $\mathrm{u}$ proseku veće nego kod jedne ugrađene patrone. Što se može objasniti delovanjem iste sile na kraćem rastojanju (nezalepljeni deo ankera). Deformacije su merene na svakih 50 bara priraštaja pritiska na presi. Ako se za sve ankere (boksit i krečnjak zajedno) naprave sumarni dijagrami za ankere sa jednom i ankere sa dve ugrađene patrone može se videti sledeće:

- za anker sa jednom ugrađenom patronom pri maksimalnoj sili od 145,2 KN (320 bara) dolazi do istezanja od 2,00 cm, dijagram 1 .

- za anker sa dve patrone pri istoj sili dolazi do istezanja od $2,70 \mathrm{~cm}$, dijagram 2 . 
Tabela 1. Vrednosti pomeranja $(\Delta l,[\mathrm{~cm}])$ u funkciji od sile čupanja - nosivosti $(F,[k N])$

\begin{tabular}{|c|c|c|c|c|}
\hline \multicolumn{5}{|c|}{ U boksitu: OH 36 } \\
\hline \hline Red.broj & Pritisak & Sila & \multicolumn{2}{|c|}{ Deformacija } \\
\hline 4 & $\mathrm{P}$ & $\mathrm{F}$ & 1 & $\Delta \mathrm{l}$ \\
\hline \multirow{2}{*}{$\begin{array}{c}\text { Broj } \\
\text { patrona } \\
\text { u bušotini }\end{array}$} & {$[$ bara $]$} & {$[\mathrm{kN}]$} & {$[\mathrm{cm}]$} & {$[\mathrm{cm}]$} \\
\cline { 2 - 5 } & 0 & 0.0 & 8.40 & 0.00 \\
\cline { 2 - 5 } & 100 & 22.7 & 8.00 & 0.40 \\
\hline $\mathbf{1}$ & 150 & 68.0 & 7.80 & 0.20 \\
\hline & 200 & 90.7 & 7.30 & 0.30 \\
\hline & 250 & 113.4 & 7.00 & 0.30 \\
\hline & 300 & 136.1 & 6.40 & 0.60 \\
\hline & 300 & 136.1 & 5.90 & 0.50 \\
\hline
\end{tabular}

\begin{tabular}{|c|c|c|c|c|}
\hline \multicolumn{5}{|c|}{ U krovinskom krečnjaku: OH 32 } \\
\hline \hline red.broj & Pritisak & Sila & \multicolumn{2}{|c|}{ deformacija } \\
\hline 1 & $\mathrm{P}$ & $\mathrm{F}$ & 1 & $\Delta \mathrm{l}$ \\
\hline \multirow{2}{*}{$\begin{array}{c}\text { Broj } \\
\text { patrona } \\
\text { u bušotini }\end{array}$} & {$[$ bara $]$} & {$[\mathrm{kN}]$} & {$[\mathrm{cm}]$} & {$[\mathrm{cm}]$} \\
\cline { 2 - 5 } & 50 & 0.0 & 9.00 & 0.00 \\
\cline { 2 - 5 } & 100 & 45.4 & 8.40 & 0.40 \\
\hline $\mathbf{1}$ & 150 & 68.0 & 8.30 & 0.10 \\
\hline & 200 & 90.7 & 8.20 & 0.10 \\
\hline & 250 & 113.4 & 7.80 & 0.40 \\
\hline & 290 & 131.5 & 7.20 & 0.60 \\
\hline & 250 & 113.4 & & \\
\hline
\end{tabular}

\begin{tabular}{|c|c|c|c|c|}
\hline Red.broj & Pritisak & Sila & \multicolumn{2}{|c|}{ Deformacija } \\
\hline 5 & $\mathrm{P}$ & $\mathrm{F}$ & 1 & $\Delta \mathrm{l}$ \\
\hline \multirow{2}{*}{$\begin{array}{c}\text { Broj } \\
\text { patrona } \\
\text { u bušotini }\end{array}$} & {$[\mathrm{bara}]$} & {$[\mathrm{kN}]$} & {$[\mathrm{cm}]$} & {$[\mathrm{cm}]$} \\
\cline { 2 - 5 } & 0 & 0.0 & 8.20 & 0.00 \\
\cline { 2 - 5 } & 100 & 22.7 & 7.70 & 0.50 \\
\hline $\mathbf{2}$ & 150 & 68.4 & 7.20 & 0.50 \\
\hline & 200 & 90.7 & 6.60 & 0.40 \\
\hline & 250 & 113.4 & 6.00 & 0.60 \\
\hline & 300 & 136.1 & 5.70 & 0.30 \\
\hline & 310 & 140.6 & 5.00 & 0.70 \\
\hline & 280 & 127.0 & puklo & \\
\hline
\end{tabular}

\begin{tabular}{|c|c|c|c|c|}
\hline Red.broj & Pritisak & Sila & \multicolumn{2}{|c|}{ Deformacija } \\
\hline 3 & $\mathrm{P}$ & $\mathrm{F}$ & 1 & $\Delta \mathrm{l}$ \\
\hline \multirow{2}{*}{$\begin{array}{c}\text { Broj } \\
\text { patrona }\end{array}$} & {$[$ bara $]$} & {$[\mathrm{kN}]$} & {$[\mathrm{cm}]$} & {$[\mathrm{cm}]$} \\
\cline { 2 - 5 } u bušotini & 0 & 0.0 & 4.50 & 0.00 \\
\cline { 2 - 5 } & 50 & 22.7 & 4.30 & 0.20 \\
\cline { 2 - 5 } & 100 & 45.4 & 3.90 & 0.40 \\
\hline $\mathbf{2}$ & 150 & 68.0 & 3.80 & 0.10 \\
\hline & 200 & 90.7 & 3.60 & 0.20 \\
\hline & 250 & 113.4 & 3.40 & 0.20 \\
\hline & 300 & 136.1 & 3.00 & 0.40 \\
\hline & 310 & 140.6 & & \\
\hline & & & & \\
\hline
\end{tabular}

Dijagram 1. ...za ankere sa jednom patronom

Dijagram 2. ...za ankere sa dve patrone
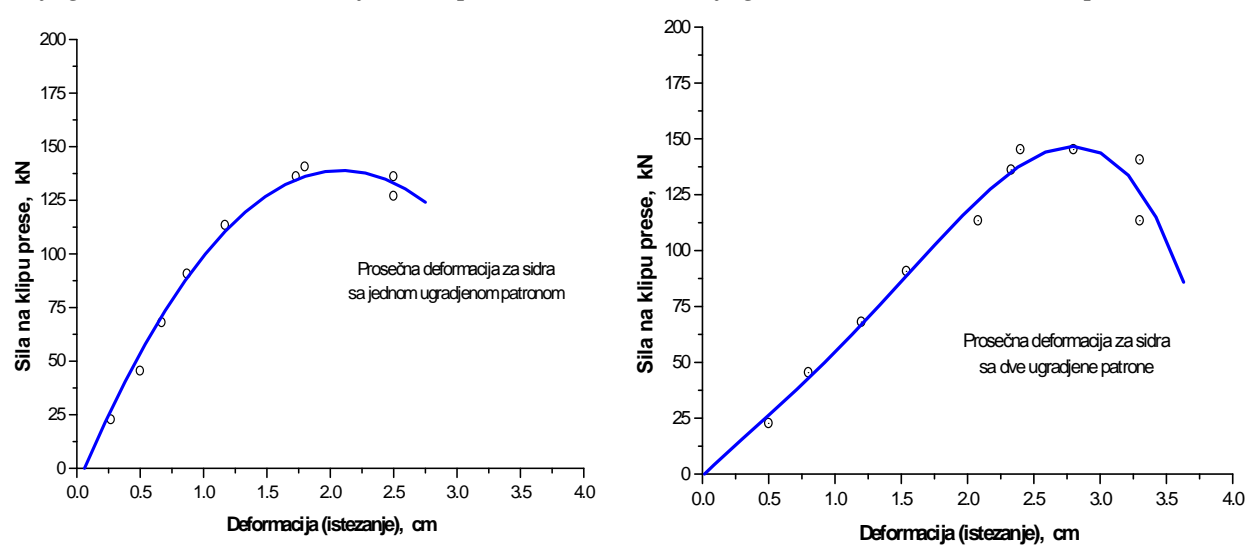

S1. 2. Dijagrami - rezultati testova čupanja ankera za radnu sredinu u jami „Biočki stan“ 


\section{Ispitivanje nosivosti ankera u rudniku uglja REMBAS, jami „Strmosten““}

U slučaju kidanja na navoju nije bilo moguće egzaktno odrediti tačnu nosivost ankera. U tom slučaju se zna da anker nosi više od $130 \mathrm{KN}$ (sila kidanja).

Iz priloženih tabela i dijagrama, a na osnovu izvršenih ispitivanja nosivosti ankera, može zaključiti da se sila istezanja (tečenja) na navoju anker kreće u granicama od 90-110 KN, a sila kidanja na navoju od 120 - $140 \mathrm{KN}$, kao i to da ispitani ankeri zadovoljavaju propisani kvalitet prema važećem standardu i atestu proizvođača.
Eksperimentalno podgrađivanje AT visećom podgradom, obavljeno je tokom 2004. godine na ukupno devet testova čupanja ankera na tri odabrane lokacije u prostorijama TH-4 i GTH-2, pri čemu se kao realna mogućnost ocenjuje negativan uticaj zdrobljenog krovinskog materijala na očitane rezultate testa. Ankeri su izrađeni od rebrastog čelika prečnika $22 \mathrm{~mm}$, a oni su instalirani u bušotinama prečnika $27 \mathrm{~mm}$. Testiranje je urađeno sa brzo vezujućim smolama, nabavljenih od proizvođača Carbotech. Ostvareni rezultati su dati u tabeli. [3]

Tabela 2. Rezultati testova čupanja kratko vezanog ankera

\begin{tabular}{|c|c|c|c|c|c|}
\hline $\begin{array}{c}\text { Br. } \\
\text { testa }\end{array}$ & Lokacija & Sredina & $\begin{array}{c}\text { Dubina } \\
\text { [m] }\end{array}$ & $\begin{array}{c}\text { Čvrstoća veze } \\
{[\mathrm{kN}]} \\
\end{array}$ & Komentar \\
\hline 1 & \multirow{3}{*}{ TH-4 } & \multirow{3}{*}{$\begin{array}{c}\text { Masiv } \\
\text { iznad } \\
\text { uglja }\end{array}$} & \multirow{3}{*}{2,4} & 123 & $\begin{array}{l}\text { Oko } 10 \% \text { gline pri vrhu } \\
\text { bušotine }\end{array}$ \\
\hline 2 & & & & 85 & $\begin{array}{c}\text { Oko } 30 \% \text { gline pri vrhu } \\
\text { bušotine }\end{array}$ \\
\hline 3 & & & & 95 & $\begin{array}{l}\text { Oko } 30 \% \text { gline pri vrhu } \\
\text { bušotine }\end{array}$ \\
\hline 4 & \multirow{3}{*}{ TH-4 } & \multirow{3}{*}{ Ugalj } & \multirow{3}{*}{1,0} & 28 & \\
\hline 5 & & & & $>70$ & $\begin{array}{l}\text { Merač uklonjen pri } 70 \mathrm{kN} \text {; } \\
\text { Anker opterećen do } 95 \mathrm{kN} \text {. }\end{array}$ \\
\hline 6 & & & & 28 & \\
\hline 7 & \multirow{3}{*}{ GTH-2 } & \multirow{3}{*}{$\begin{array}{l}\text { Crveni } \\
\text { peščar }\end{array}$} & \multirow{3}{*}{1,1} & 37 & \multirow{3}{*}{$\begin{array}{l}\text { Peščar potpuno zdrobljen i pod } \\
\text { opterećenjem. }\end{array}$} \\
\hline 8 & & & & 28 & \\
\hline 9 & & & & - & \\
\hline
\end{tabular}

Treba napomenuti da pojmom "čvrstoća veze" podrazumeva trenutak kada krutost veze anker - smeša - masiv, padne ispod vrednosti od $20 \mathrm{kN} / \mathrm{mm}$ veze. Da bi se test ocenio kao uspešan, preporučena sila čupanja kratko vezanog ankera (u dužini od $300 \mathrm{~mm}$ ) iznosi $130 \mathrm{kN}$, što treba ostvariti na preko $50 \%$ dužine bušotine za anker. 


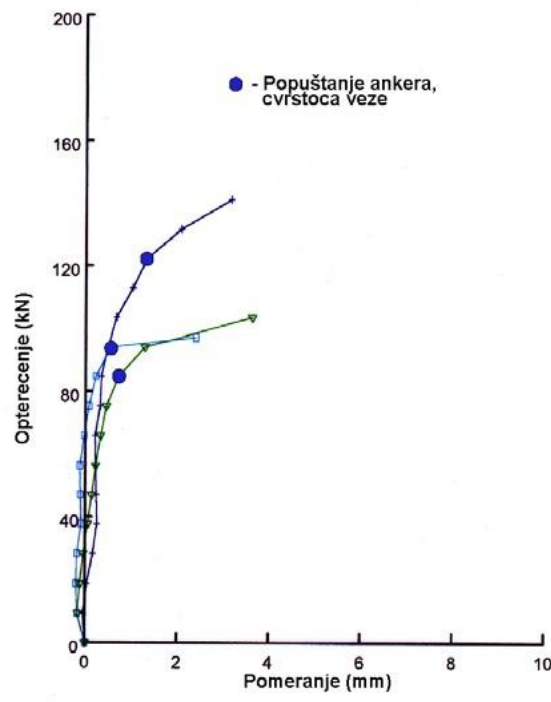

a) Test čupanja ankera u TH-4 dužine 2,4 m, iz masiva iznad uglja

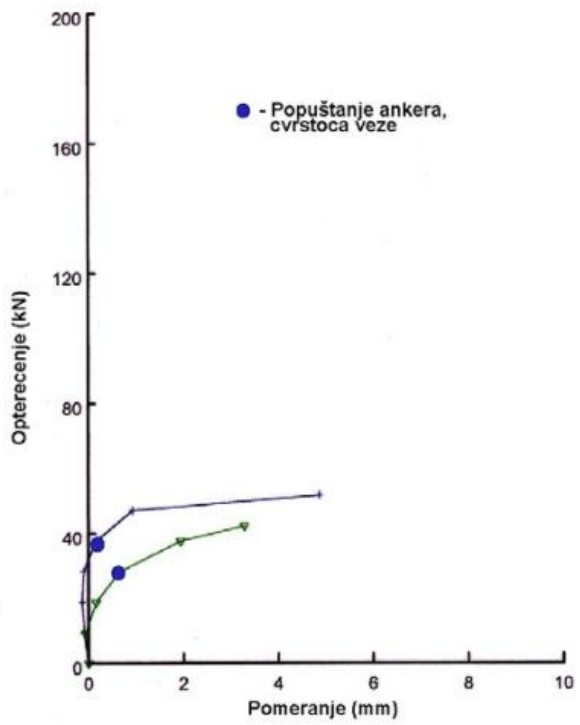

c) Test čupanja ankera u GTH-2 dužine 1,1 m, iz crvenog peščara

Sl. 3. Dijagrami - rezultati testova čupanja ankera za radnu sredinu u jami „,Strmosten“
Rezultati ukazuju da se čvrstoća od 123 $\mathrm{kN}$ može ostvariti u delu u kome se anker nalazi u peščaru i laporcu, dok se u uglju mogu očekivati čvrstoće $u$ granicama od 70

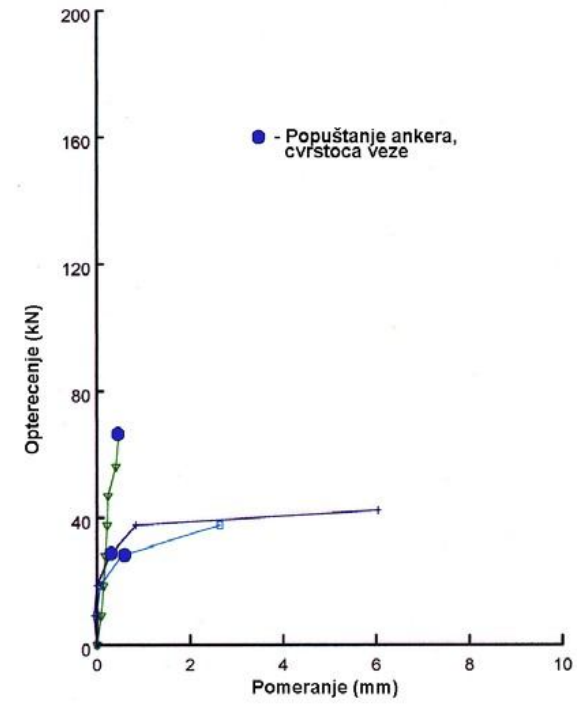

b) Test čupanja ankera u TH-4 dužine 1,0 m, iz uglja do $95 \mathrm{kN}$. Izdrobljeni i poremećeni masiv $\mathrm{u}$ okolini podzemne prostorije je verovatno nepovoljno uticao na neke od rezultata testa. 
Zaključeno je da su ispunjeni kriterijumi na osnovu kojih se AT viseća podgrada u podzemnoj prostoriji TH-4 jame ,Strmosten" rudnika REMBAS može oceniti kao efikasna. Takođe je dokazano da je AT viseća podgrada reagovala sastenskim masivom, odnosno da je preuzela kako vertikalna tako i horizontalna opterećenja.

Ostvarena stabilnost podzemne prostorije, primenom AT viseće podgrade, $u$ velikoj meri garantuje smanjenje potreba za rekonstrukcijom prostorija otkopne pripreme i ujedno pružaju mogućnosti za dalja istraživanja u pogledu optimizacije načina podgrađivanja, prvenstveno u smeru pove- ćanja rastojanja između okvira čelične podgrade, pa čak i do njene potpune eliminacije.

\section{Ispitivanje nosivosti ankera u Rudnicima bakra u Boru, rudniku ,Jama“6}

U toku podzemnog otkopavanja, uporedo sa eksploatacijom rude, u cilju obezbeđenja podzemnog otkopa $\mathrm{u}$ rudnom telu „T1“", vršeno je eksperimentalno podgrađivanje otkopnog prostora. Podgrađivanje se vršilo ankerima tipa SWELLEX i SN, M-20 u kombinaciji sa smolom LOKSET RESIN CAPSULES. Podgrađivanju prethodi bušenje bušotina za ugradnju ankera. Prečnik bušotina je $\varnothing 33 \mathrm{~mm}$ i dužine $3 \mathrm{~m}$. [4]

Tabela 3. Vrednosti pomeranja $(\Delta l,[\mathrm{~mm}])$ u funkciji od sile čupanja-nosivosti $(F,[\mathrm{kN}])$

\begin{tabular}{|c|c|c|c|c|c|}
\hline \multicolumn{6}{|c|}{ Anker - mesto ispitivanja } \\
\hline \multicolumn{2}{|c|}{ Proba 1, bok prostorije K-145 } & \multicolumn{2}{|c|}{ Proba 2, desni bok K-145 } & \multicolumn{2}{|c|}{ Proba 3, levi bok, K-145 } \\
\hline$\Delta \mathrm{l},[\mathrm{mm}]$ & $\mathrm{F},[\mathrm{kN}]$ & $\Delta \mathrm{l},[\mathrm{mm}]$ & $\mathrm{F},[\mathrm{kN}]$ & $\Delta \mathrm{l},[\mathrm{mm}]$ & $\mathrm{F},[\mathrm{kN}]$ \\
\hline 4,30 & 18,64 & 7,00 & 18,64 & 1,00 & 9,32 \\
\hline 8,80 & 46,60 & - & - & 2,60 & 18,64 \\
\hline 10,00 & 55,92 & - & - & 3,30 & 37,28 \\
\hline 11,30 & 65,24 & - & - & 4,20 & 46,60 \\
\hline 12,60 & 74,56 & - & - & 4,80 & 55,92 \\
\hline 14,20 & 83,88 & - & - & 5,00 & 65,24 \\
\hline 15,70 & 82,30 & - & - & 5,80 & 74,56 \\
\hline- & - & - & - & 7,00 & 83,88 \\
\hline \multicolumn{6}{|c|}{ Anker - mesto ispitivanja } \\
\hline \multicolumn{2}{|c|}{ Proba 1, desni bok K-123 } & \multicolumn{2}{|c|}{ Proba 2, desni bok K-123 } & \multicolumn{2}{|c|}{ Proba 3, strop prostorije K-123 } \\
\hline$\Delta \mathrm{l},[\mathrm{mm}]$ & $\mathrm{F},[\mathrm{kN}]$ & $\Delta \mathrm{l},[\mathrm{mm}]$ & $\mathrm{F},[\mathrm{kN}]$ & $\Delta \mathrm{l},[\mathrm{mm}]$ & $\mathrm{F},[\mathrm{kN}]$ \\
\hline 7,10 & 18,64 & 3,00 & 18,64 & 2,00 & 18,64 \\
\hline 7,60 & 27,96 & 3,20 & 27,96 & 6,10 & 27,96 \\
\hline 8,20 & 37,28 & 4,00 & 37,28 & 7,50 & 37,28 \\
\hline 8,40 & 46,60 & 5,90 & 46,60 & 10,50 & 46,60 \\
\hline 8,50 & 55,92 & 6,00 & 55,92 & 11,00 & 55,92 \\
\hline 9,20 & 65,24 & 7,10 & 65,24 & 13,00 & 60,58 \\
\hline 13,30 & 74,56 & 7,40 & 74,56 & 14,00 & 65,24 \\
\hline 15,90 & 83,88 & 8,00 & 83,88 & 14,80 & 74,56 \\
\hline 17,70 & 93,20 & 9,80 & 93,20 & 15,00 & 83,88 \\
\hline 18,60 & 102,52 & 9,90 & 102,52 & 15,10 & 93,20 \\
\hline 19,40 & 111,84 & 10,00 & 111,84 & 16,00 & 102,52 \\
\hline 23,50 & 121,16 & 12,90 & 121,16 & 16,30 & 111,84 \\
\hline 26,00 & 130,48 & 13,00 & 130,48 & 16,50 & 121,16 \\
\hline 27,00 & 135,14 & 13,50 & 139,80 & 25,50 & 130,48 \\
\hline- & - & 16,70 & 149,12 & - & - \\
\hline - & - & 17,40 & 153,78 & - & - \\
\hline
\end{tabular}


Nakon ugradnje ankera, vršeno je njihovo naprezanje, zatim postavljanje armaturne mreže i nanošenje torkret betona. Pored sile čupanja registrovana su i pomeranja glave ankera. Sila čupanja se nanosi postepeno do dostizanja zadate (radne) ili granične sile čupanja. Rezultati ispitivanja nosivosti ankera su prikazani su tabelarno, a karakteristični primeri i na grafičkim dijagramima pomeranja u funkciji sile čupanja.

Merenja su izvršena u dva navrata (novembra 2013. godine i januara 2014. godine) na 6 ankera, koji su ugrađeni na karakterističnim mestima u rudnom telu ,T1“.

Dijagram nosivosti ankera

Proba 1, bok prostorije, K-145

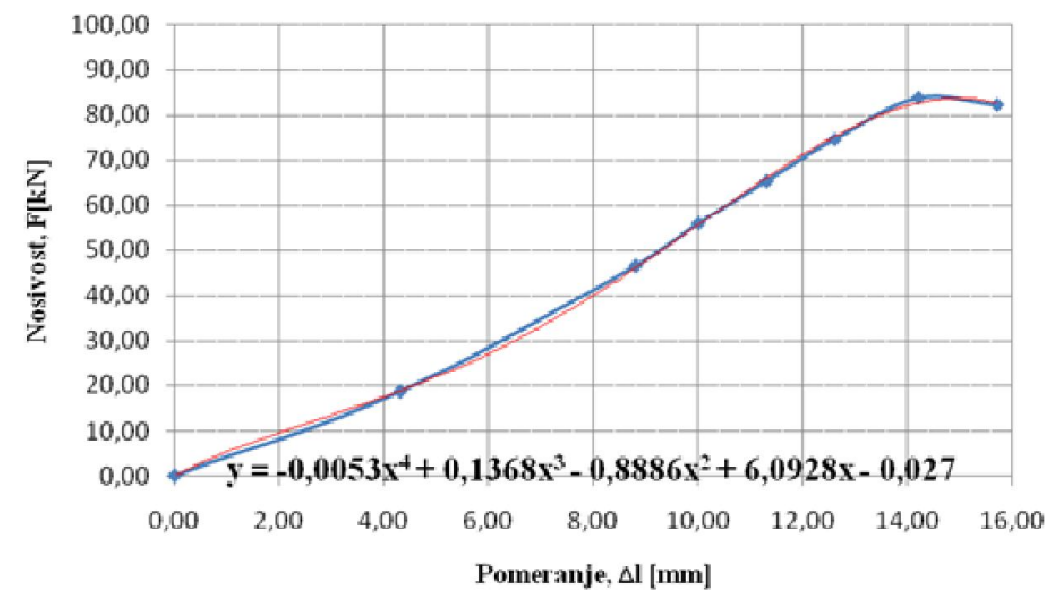

Dijagram nosivosti ankera

Proba 3, strop prostorije, raskrsnica, K-123

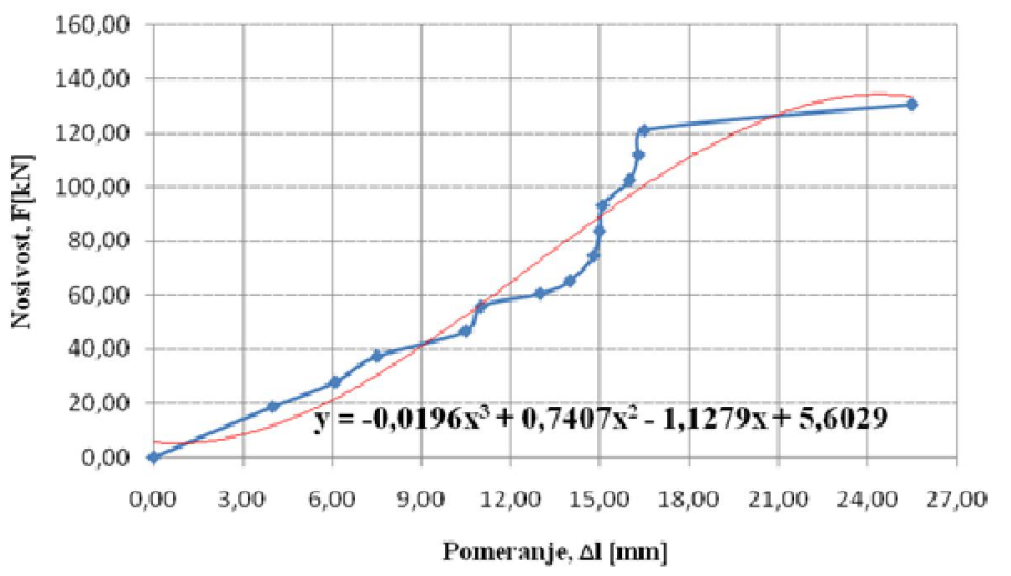

S1. 4. Dijagrami - rezultati testova čupanja ankera za radnu sredinu u jami „Bor“

Vrednosti sila čupanja ankera su upoređene sa specifikacijom i atestom, koje je dao proizvođač i zaključeno je da ankeri u potpunosti ispunjavaju svoju funkciju. 


\section{ANALIZA REZULTATA}

Testirani ankeri sa kontinualnim učvršćenjem (AT ankeri) su i na primeru eksperimentalnog testiranja $\mathrm{u}$ različitim radnim sredinama potvrdili daispunjavaju zadatu funkciju i imaju sledeće prednosti [6]:

- Vezu između ankera i stene je lakše ostvariti, a sama veza je pouzdanija i nezavisna od vrste stene;

- Efikasnost ankera je trajna i to celom dužinom ankera;

- Ankeri sa kontinualnim učvršćenjem sprečavaju vertikalne i horizontalne deformacije masiva;

- Dubina bušotine nije ključni parametar, pošto se veza između ankera $\mathrm{i}$ masiva može uskladiti sa vrstom stene;

- Ankeri sa kontinualnim učvršćivanjem sprečavaju tok vode i strujanje vazduha, tako da se eliminiše korozija ankera i uticaj vlage iz vazduha na stenu;

- Oštećenja navrtke, navoja i ostalih elemenata ankera, kao i drobljenje stene oko samog ankera, ne smanjuje efikasnost veze anker-smeša-stena;

- Ankera sa dvokomponentnom smešom (baziranoj na polimernim smolama) mogu izdržati uticaj miniranja bez gubitka nosivosti i

- Ankera sa dvokomponentnom smešom su posebno efikasna u slučaju delimitčnog popuštanja veze ankera sa stenom.

Takođe, i podaci o nosivosti ankera, dobijeni testiranjem čeličnih ankera sa dvokomponentnom smešom, predstavljaju relevantne ulazne podatake za programe proračuna nosivosti i analizu stabilnosti podzemnih objekata.

\section{ZAKLJUČAK}

Eksperimentalnim testiranjem utvrđena je efikasnost AT viseće podgrade rezultujući zaustavljanje širenja deformacija po dubini masiva (što predstavlja dokaz postizanja stabilnosti podzemne prostorije) i ostvarivanje transfera opterećenja sa stenskog masiva na AT viseću podgradu.

Nominalna nosivost testiranih ankera prečnika $22 \mathrm{~mm}$ može da se za sve potrebne proračune usvoji da je nosivost ankera 150 $\mathrm{KN}$ (nosivost ankera na istezanje).

Ostvareni rezultati pružaju mogućnosti za dalja istraživanja u pogledu optimizacije načina podgrađivanja, prvenstveno u pravcu definisanja šeme i rasporeda ugradnje ankera, ali i utvrđivanja neophodnog broja patrona dvokomponentne smeše po bušotini. Evidentirano je da se u nekim slučajevima, ankeri lepljeni samo sa jednom patronom dužine $30 \mathrm{~cm}$ (dužina lepljenja $50 \mathrm{~cm}$ ) nisu popustili i dolazilo je do istezanja ili kidanja. Time se otvara i pitanje mogućnosti optimazacije broja patrona odnosno dužine lepljenja ankera u bušotini u zavisnosti od dužine ankera i karakteristika stenskog masiva.

\section{LITERATURA}

[1] ASTM F432-04, Standard Specification for Roof and Rock Bolts and Accessories, ASTM International, Pensilvanija, SAD, 2004.

[2] Elaborat o testiranju i davanju atesta za čelična sidra sa dvokomponentnom smešom, „Uvođenje tehnologije sidrenja u rudnicima boksita Nikšić - I faza“, Rudarski Institut Zemun, maj, 2001. 
[3] V. Milisavljević, Doktorska disertacija, Izbor elemenata sistema AT viseće podgrade za rudnike uglja sa podzemnom eksploatacijom u Srbiji, Rudarsko-geološki fakultet u Beogradu, 2010.

[4] Kvartalni izveštaj o stanju radova na eksploataciji rude iz rudnog tela „T1“, Institut za rudarstvo i metalurgiju Bor, mart 2014.

[5] D. Ignjatović, L. Đurđevac Ignjatović, M. Ljubojev, I. Ivanov, Ispitivanje nosivosti ankera u rudnom telu „T1“,
Mining and Metallurgy Engineering Bor, 1/2014, str. 7-12.

[6] Peng, S. and Tang, D.: Roof Bolting in Underground Mining: State of the Art View, International Journal of Mining Engineering, v. 2, str. 1-4, 1984.

[7] M. Ljubojev, M. Avdić, L. Đurđevac Ignjatović; State around the mine workings; The $44^{\text {th }}$ International October Conference on Mining and Metallurgy 1-3 October 2012, Bor; str. 245-248; Serbia 